\title{
A change of tone オバマ政権の科学技術政策
}

Nature Vol. 460(781)/13 August 2009

オバマ政権の科学に対する姿勢には、楽観視してよい十分な理由がある。

2009 年 1 月、バラク・オバマが大統領に就任し、心地よ い満足感が米国の首都ワシントン DCをほぼ覆いつくし た。しかし夏になると、医療制度改革、金融規制といった 論点をめぐって議会での与野党対立が行き詰まりをみせ、 高揚感は薄れてしまった。

それでも積極的な施策が静かに実施されつつある。例 えば 8 月 6 日には、科学技術担当大統領補佐官であるジョ ン・ホルドレン（大統領府科学技術政策局長官を兼務）が、 大学と産業界の著名な研究者 21 人によって構成される大 統領科学技術諮問委員会（PCAST）の初めての会議を招 集した。

第 1 回 PCAST 会議は、委員の意気込从が大きかった反 面、委員会の実効性を示す証拠は乏しかった。ただ新政権 発足当初の会議であり、仕方のない面はある。ホルドレン には、核拡散防止とエネルギー問題に関する幅広い知識と 経験を、今回の職責に生かすことが期待されている。彼は、 新型インフルエンザ $(\mathrm{H} 1 \mathrm{Nl})$ の世界的流行への政府対応 策に関して、最初の PCAST 報告書を数週間以内に公表す ベく準備作業を進めている、と述べた。この会議では、医 療記録の電子化や治療法の有効性比較研究といつたテーマ に関して活発な議論が行われ、PCAST の提言に大統領府 が耳を傾けるよう各委員が大きな期待感をもつていること が垣間見えた。

また 8 月 4 日には、ホルドレンとピーター・オルザグ 大統領府行政管理予算局長が、2011 年度予算の概算要求 の策定開始時期を迎えた連邦政府各部署の高官にあてて、 オバマ政権の優先課題を概説したメモを作成、署名した。
このメモでは、景気回復、医療、エネルギー、気候などの 優先課題において、科学技術が重要な役割を果たす点が強 調された。そして、「政策決定は、健全な科学に基づいて なされるべきである」という殺し文句が付記された。

このような姿勢は、いつも科学を二の次にしてきたブッ シュ前政権では、ほとんどみられなかったことだ。先 週、共和党と民主党の元上院議員 4 人が 2007 年にワシ ントンDCで設立したシンクタンク「Bipartisan Policy Center」による報告書が発表されたが、そこでも、政治 的意思決定に科学を正しく取り入れるために、多くのと るべき行動があることを指摘している。常識と思われる 事柄が具体的に提言されており、例えば新設の規則を提 案する際には、解明する必要のある科学的疑問点を明示 しなければならないこと、科学諮問委員会に任命される 者に適用される利益相反ルールを明確化すべきこと、な どである。ブッシュ前政権時代には、科学的事柄に関す る常識の欠如が頻繁にみられた。

今後、ホルドレンは数多くの課題に直面することになる。 その中には、主要な科学技術予算案件の正当性に関する議 会の納得を得るために支援を行うこと、そのような案件の 成否を明確に説明する経過報告書を提出することも含まれ る。ところが大統領府で彼を支えるチームは未完成状態だ。 科学技術政策局次長は 4 人と定められているが、科学担 当と国家安全保障担当が現在でも空席で、有能な人材をで きるだけ早く任命しなければならない。それでも全体的に みれば、オバマ時代の科学助言体制は、好スタートを切つ たといえよう。(菊川要 訳) 